\title{
CDON wt Allele
}

National Cancer Institute

\section{Source}

National Cancer Institute. CDON wt Allele. NCI Thesaurus. Code C51021.

Human CDON wild-type allele is located within 11q23-q24 and is approximately $103 \mathrm{~kb}$ in length. This allele, which encodes cell adhesion molecule-related/down-regulated by oncogenes precursor protein, plays a role in myogenic differentiation. 